\title{
Radionuclide Disperse to Environtment from Pwr Reactor on Severe Accident Condition using Maccs Program
}

\author{
Sri Kuntjoro, Pande Made Udiyani
}

Center for Nuclear Reactor Technology and Safety - BATAN, Kawasan Puspiptek Gd. 80, Setu, Tangerang Selatan

\section{Abstract}

The atmosphere is an important pathway in the transfer of radionuclides from nuclear power plants into the environment and population. Acceptance of radiation dose to the environment and population affected by the radionuclides release and site conditions surrounding of the nuclear power plant. The radionuclides release in the atmosphere is determined by the dispersion coefficient parameter. The aim of this paper is to obtain dispersion coefficient and radionuclide released in Sebagin (West Bangka district) caused by severe accident condition from the PWR Nuclear Power Plant. Dispersion analysis of

Corresponding Author: Sri Kuntjoro, Pande Made Udiyani, email: srikuncoro@batan.go.id, pmade-u@batan.go.id

Received: 29 July 2016 Accepted: 21 August 2016 Published: 21 September 2016

\section{Publishing services} provided by Knowledge E

(c) Sri Kuntjoro, Pande Made Udiyani. This article is distributed under the terms of the Creative Commons Attribution License, which permits unrestricted use and redistribution provided that the original author and source are credited.

Selection and Peer-review under the responsibility of the ICONETS Conference Committee.

\section{G OPEN ACCESS} radionuclides into the environment from nuclear power PWR on severe accident conditions have been done using MACCS program. Reference for the calculation of source term fraction is selected from calculation results of the MELCOR computer code and it is implemented to PWR reactors Westinghouse 3411 MWth subject. The calculation of radionuclides release performed using MACCS program for aspiring nuclear power plant site in West Bangka. Simulation calculations for the area radius from $0.80 \mathrm{kmup}$ to $20 \mathrm{~km}$ from the nuclear power plant site are performed. Meteorological datas used in calculation are the meteorology data from Sebagin meteorological stations for the years of 2012 period. The result is the dispersion coefficient decreases as a function of time and distance. The concentration of radionuclides through soil pathway decreases as a function of the distance, and the dominant contributor of radionuclide radiation $\mathrm{Xe}-133$ and I-131. Radionuclide concentrations obtained through the air pathway decreases as a function of distance, and dominant contributors of radionuclide radiation is contributed also from I-131 and Xe-133. The presence of I-131 radionuclides are giving dangerous to humans, it is necessary to further treatment for prevent its impacts.

Keywords: dispersion coefficient, radionuclide concentration, severe accident, MACCS

\section{Introduction}

Nuclear energy is one of the alternative energy being considered by the Indonesian government to maintain availability of national energy. The existence of nuclear energy implemented to build Nuclear Power Plant (NPP). According to the existence of a nuclear power plant in reactor site is requires assessment of nuclear safety to monitor and minimize the impact this may have. According to this condition, determine analysis of the consequences of radionuclides releases to the environment and population. Based on this 
analysis it can be seen how big the consequences and the radiation dose to be public and the environment due to the condition of an accident on the rector. Radionuclides release into the environment and population can result from normal and abnormal operation of nuclear power plants. The mostly radionuclide release is through to the air, which is the radionuclide release to atmosphere.

Based on radioactive exposure pathway, radionuclide dispersion in the air will be partially deposited in the ground and will culminate in the environment through the food chain to population. The distribution of radionuclides in the atmosphere is determined by the parameters of the dispersion coefficient, while the deposition parameters are influenced by the dispersion parameter. Dispersion parameters will affected to the external and internal exposure coming from radioactive cloud, while the deposition parameters will affect to the internal and external exposure coming from radioactive deposition on the ground surface. Dispersion parameter is a parameter that is analyzed and written on the Safety Analysis Report (SAR) as part of Chapter on NPP accident analysis. Dispersion parameters can be estimated using Gaussian Plume Model (GPM) as used in computer codes TREX (Hungary), MACCS (Taiwan, USA), OSCAAR (Japan), LENA (Brazil ), and using Lagrangian Plume Model (LPM) as used in computer codes HYSPLIT (USA), NAME III (UK), MINERVE-SPRAY (CEA-France) $[1,2,3,4,5,6,7]$. Estimation data of dispersion parameters for Muria Peninsula site plant simulation analyzed using the PC-Cosyma code has been successfully carried out[8,9]. The dispersion parameter estimation data for a potential NPP site in Indonesia is very necessary used for build of NPP SAR document, such as for prospective new site is Bangka Belitung site. Since the dispersion coefficient data for the Bangka Belitung site have not been estimated, then the research in this field will estimated using MACCS (USA) code.

The purpose of this research is to obtain dispersion coefficient data to Sebagin (West Bangka) site using MACSS2 codes. In this research, the analysis of the dispersion coefficient and concentration of radionuclide releases for severe accident conditions in nuclear power plants with a capacity of $1000 \mathrm{MWe}$ PWR reactor type. Results of this analysis are the of radionuclide dispersion patterns from nuclear power plant site and it can be able to fill on reactor accident analysis chapter in the SAR reactor. Postulation selected is a severe accident condition and the specific reactor site to be choose is Sebagin-West Bangka site. The analysis was performed for the dispersion coefficient of $8^{\text {th }}$ fission product groups radionuclides are release from the NPP are the noble gas, lanthanides, precious metals, halogens, alkali metals, tellurium, cerium, strontium and barium groups. Calculations using removable fraction of radionuclides in PWR reactors Westinghouse is calculate using MELCOR code $[10,11]$.

\section{Theory}

Atmospheric dispersion modeling is basically an attempt to describe the functional relationship between pollutants emissions accordance pathways and resulting of radiation concentrations of radiation. Beside this is to predict radiological consequences cause of radionuclide concentration and radiological dose from various hypothetical scenarios are determine. In this study of radionuclides release through the atmospheric model using segmented Gaussian model Plume Models (GPM)[12]. Gaussian Plume Models general equations written in the following formula;

$\chi(\mathrm{x}, \mathrm{y}, \mathrm{z})=\frac{\mathrm{Q}}{2 \pi \sigma_{\mathrm{y}} \sigma_{\mathrm{z}} \mathrm{v}} \cdot \exp \left(-\frac{\mathrm{y}_{2}}{2 \sigma_{\mathrm{y}}^{2}}\right) \cdot\left\{\exp \left[-\frac{(\mathrm{z}-\mathrm{H})^{2}}{2 \sigma_{\mathrm{z}}^{2}}\right]+\exp \left[-\frac{(\mathrm{z}+\mathrm{H})^{2}}{2 \sigma_{\mathrm{z}}^{2}}\right]\right\}$ 
with;

$x(x, y, z)$ : concentration in air (chi) in axial, $x$ premises to wind direction, $y=$ perpendicular to wind direction, and $z=$ high to the ground level, $\left(\mathrm{Ci} / \mathrm{m}_{3}\right)$

Q : Radioactive release from stack, (Ci/s)

$\mathrm{u}$ : average wind velocity $(\mathrm{m} / \mathrm{s})$

$\sigma_{y}$ : segmented plume in horizontal direction $(m)$;

$\sigma_{z} \quad$ : segmented plume in vertical direction $(m)$

$H \quad$ : effective high of stack (m)

y : rectangular distance from wind direction $(\mathrm{m})$;

$\mathrm{z}$ : high distance from ground level $(\mathrm{m})$;

$\mathrm{X} / \mathrm{Q}$ : dispersion factor parameter ( $\mathrm{s} / \mathrm{m} 3)$

Magnitude early for calculation are a plum long $\mathrm{L}$, vertical and horizontal standard deviation $\sigma_{y,} \sigma_{z}$ as follows;

$$
\begin{aligned}
& L=\sum_{i} \Delta t_{i} \cdot v_{i} \\
& \sigma_{y}(t=0)=\frac{w_{b}}{4.3} \\
& \sigma_{z}(t=0)=\frac{H_{b}}{4.3}
\end{aligned}
$$

with;

$\Delta \mathrm{t}_{\mathrm{i}} \quad$ : establishment time for segmentation plume

$v_{i}$ : establishment velocity for segmentation plume

$\mathrm{W}_{\mathrm{b}}$ : width of the building where the plums are formed

$\mathrm{H}_{\mathrm{b}}$ : high of the building where the plums are formed

While the equation of the plume growth (plume are usually hot, so it will be grow up), it can be seen in the following equation;

$$
\Delta h=\frac{1.6 F^{1 / 3} X^{2 / 3}}{\overline{\mathrm{u}}}
$$

with;

$\Delta \mathrm{h}$ : magnitude of plume grow (m)

$\mathrm{F}$ : flux buoyancy from segmentation plume is $8.79 \mathrm{E}-05 \mathrm{Q}(\mathrm{m} 4 / \mathrm{s} 3)$

Q : power distribution of heat (watt)

$X$ : distance of radial downstream wind $(m)$

$\overline{\mathrm{u}}$ : average wind velocity $(\mathrm{m} / \mathrm{s})$

\section{Methodology}

The research methodology includes a series of calculations and simulations based on postulations data, assumptions data and also based on secondary and primary data namely:

- Source term Calculation for PWR type reactor with 1000 MWe power with postulation of accident is severe accident conditions of Station Black Out (SBO), and release fraction of calculation take from MELCOR calculation results of The Westinghouse PWR reactor with power 3411 MWTh. 
- Calculation of dispersion and deposition parameters using MACCS code

- Reactor site input covering meteorology and topographical conditions were wind speed, weather stability, and solar energy in 16 wind direction and 12 radius distance $(800 \mathrm{~m}, 1 \mathrm{~km}$, $2 \mathrm{~km}, 3 \mathrm{~km}, 4 \mathrm{~km}, 5 \mathrm{~km}, 6 \mathrm{~km}, 7 \mathrm{~km}, 8 \mathrm{~km}, 9 \mathrm{~km}, 10 \mathrm{~km}, 15 \mathrm{~km}$ and $20 \mathrm{~km}$ from the

- Nuclear power plant site. The selected topology data were taken from West Bangka data as well as the meteorological data were taken from the period of January to August 2012 with one hour interval time. The weather data is taken from $60 \mathrm{~m}$ from ground level and a chimney reactor height is $100 \mathrm{~m}$

- The calculation is done for the fission product releases to sequences within 1-96 hours.

\section{Result and Discussion}

\section{Sourceterm Analysis}

The analysis was first performed by calculating the reactor inventory. Further calculations was to determine reactor source term for severe accident conditions SBO using MELCOR fraction transport of severe accident SBO from PWR Westinghouse reactor with 3411 MWth power. It radionuclide fraction released results are shown in Table 1. Furthermore, in Table 2 the reactor source term assumed for this SBO accident.

TABLE 1: Fraction of radionuclide release from MELCOR calculation.

\begin{tabular}{|c|l|l|l|l|c|}
\hline \multirow{2}{*}{ No. } & \multirow{2}{*}{ Radionuclide Group } & \multicolumn{3}{|c|}{ Release Fraction of Radionuclide from Reactor (MELCOR) } \\
\cline { 3 - 6 } & & GAP & In-Vessel & Ex-Vessel & Late In-Vessel \\
\hline 1 & Noble Gas (Xe/Kr) & $1.23 \mathrm{E}-02$ & $8.94 \mathrm{E}-01$ & $8.19 \mathrm{E}-02$ & $5.88 \mathrm{E}-03$ \\
\hline 2 & Halogen (I) & $4.58 \mathrm{E}-02$ & $7.64 \mathrm{E}-01$ & $6.80 \mathrm{E}-02$ & $3.23 \mathrm{E}-03$ \\
\hline 3 & Alkali Metal (Cs) & $3.94 \mathrm{E}-03$ & $6.40 \mathrm{E}-01$ & $1.02 \mathrm{E}-01$ & $2.41 \mathrm{E}-03$ \\
\hline 4 & Te & $4.97 \mathrm{E}-03$ & $6.57 \mathrm{E}-01$ & $2.65 \mathrm{E}-02$ & $3.32 \mathrm{E}-03$ \\
\hline 5 & Ba, Sr & $4.97 \mathrm{E}-03$ & $2.00 \mathrm{E}-03$ & $2.35 \mathrm{E}-02$ & $1.36 \mathrm{E}-09$ \\
\hline 6 & Ru & $4.97 \mathrm{E}-03$ & $9.75 \mathrm{E}-03$ & $2.09 \mathrm{E}-02$ & $1.75 \mathrm{E}-05$ \\
\hline 7 & Lathanium (La) & $4.97 \mathrm{E}-03$ & $1.06 \mathrm{E}-07$ & $1.19 \mathrm{E}-04$ & $1.93 \mathrm{E}-13$ \\
\hline 8 & Ce & $4.97 \mathrm{E}-03$ & $1.01 \mathrm{E}-07$ & $4.96 \mathrm{E}-03$ & $1.34 \mathrm{E}-13$ \\
\hline 9 & Mo & $4.97 \mathrm{E}-03$ & $4.61 \mathrm{E}-01$ & $2.31 \mathrm{E}-10$ & $3.44 \mathrm{E}-03$ \\
\hline
\end{tabular}

Release fraction in the reactor building depends on the type and character of fission products, and the noble gases have the largest release fraction for each place because of the nature of noble gases do not react with the material. As for fission products which is volatile type such as alkali metal (Cs) and halogen (I) has a little more fraction compare with the noble gases release. Based on released fraction of radionuclides from reactor core to the chimney (late vessel) as written in Table 1, the source term results are listed in Table 2.

Table 2 shows that radionuclide source term from the Noble Gas group (I, Xe and $\mathrm{Kr}$ ) have a high level of radiation that is in order of $10^{12}$, this is because the Noble Gas has properties that cannot be filtered, so most of the radionuclides in this group can escape to the environment. Furthermore the source term results in Table 2 are used for the calculation of dispersion parameters and radionuclides concentration are dispersed through the ground and the air. 
TABLE 2: Reactor source term (Bq).

\begin{tabular}{|c|c|c|c|c|c|}
\hline No & Radionuclides & Source term (Bq) & No & Radionuclides & Source term (Bq) \\
\hline 1 & $K R-85$ & $4.72 \mathrm{E}+10$ & 26 & $\mid-131$ & $1.18 \mathrm{E}+13$ \\
\hline 2 & $\mathrm{KR}-85 \mathrm{M}$ & $9.99 \mathrm{E}+11$ & 27 & $\mid-132$ & $1.27 \mathrm{E}+13$ \\
\hline 3 & $\mathrm{KR}-88$ & $2.47 E+12$ & 28 & |-133 & $2.36 E+13$ \\
\hline 4 & RB-86 & $2.26 \mathrm{E}+09$ & 29 & $\mid-134$ & $1.18 \mathrm{E}+13$ \\
\hline 5 & SR-89 & $4.92 \mathrm{E}+02$ & 30 & |-135 & $2.04 E+13$ \\
\hline 6 & SR-90 & $4.23 \mathrm{E}+01$ & 31 & $X E-133$ & $8.55 E+12$ \\
\hline 7 & $Y-90$ & $4.68 \mathrm{E}-01$ & 32 & $X E-135$ & $3.61 E+12$ \\
\hline 8 & Y-91 & $2.97 \mathrm{E}-01$ & 33 & CS-134 & $1.91 \mathrm{E}+11$ \\
\hline 9 & $Y-92$ & $1.05 E+02$ & 34 & CS-137 & $1.11 \mathrm{E}+11$ \\
\hline 10 & ZR-95 & 3.17E-08 & 35 & BA-139 & $5.42 \mathrm{E}+02$ \\
\hline 11 & ZR-97 & $3.00 \mathrm{E}-08$ & 36 & BA-140 & $8.68 \mathrm{E}+02$ \\
\hline 12 & NB-95 & $3.19 \mathrm{E}-08$ & 37 & LA-140 & $1.53 \mathrm{E}+01$ \\
\hline 13 & MO-99 & $5.21 \mathrm{E}+07$ & 38 & LA-141 & $2.58 \mathrm{E}-08$ \\
\hline 14 & TC-99M & $4.68 \mathrm{E}+07$ & 39 & LA-142 & $1.91 \mathrm{E}-08$ \\
\hline 5 & RU-103 & $4.15 E+07$ & 40 & $C E-141$ & $8.55 \mathrm{E}-07$ \\
\hline 16 & RU-105 & $2.42 \mathrm{E}+07$ & 41 & $C E-143$ & $7.84 \mathrm{E}-07$ \\
\hline 17 & RU-106 & $1.37 \mathrm{E}+07$ & 42 & CE-144 & $6.46 \mathrm{E}-07$ \\
\hline 18 & $\mathrm{RH}-105$ & $2.58 \mathrm{E}+07$ & 43 & PR-143 & $2.95 \mathrm{E}-08$ \\
\hline 19 & SB-127 & $4.72 \mathrm{E}+10$ & 44 & ND-147 & 1.23E-08 \\
\hline 20 & SB-129 & $1.21 \mathrm{E}+11$ & 45 & NP-239 & $1.00 \mathrm{E}-05$ \\
\hline 21 & $\mathrm{TE}-127$ & $4.71 \mathrm{E}+10$ & 46 & PU-241 & $5.83 \mathrm{E}-08$ \\
\hline 22 & $\mathrm{TE}-127 \mathrm{M}$ & $6.09 E+09$ & 47 & $\mathrm{AM}-241$ & $2.40 \mathrm{E}-12$ \\
\hline 23 & TE-129 & 1.36E+11 & 48 & $C M-242$ & $5.63 \mathrm{E}-10$ \\
\hline 24 & TE-129M & $2.07 E+10$ & 49 & CM-244 & $6.91 E-11$ \\
\hline 25 & $T E-132$ & $6.31 \mathrm{E}+11$ & & & \\
\hline
\end{tabular}

\section{Weather Analysis in Sebagin Meteorology Station on West Bangka District}

Weather analysis is conducted by describing the Wind Rose and it used to determine the direction and speed of the dominant wind blows from the nuclear power plant site in West Bangka district. Meteorological data are then used as input of the MACCS codes. The results of wind rose can be seen in Figure 1.

Figure 1 shows that the largest distribution of radionuclides to the South-East (zone 6 to 8 ), the West and the Southwest (zones 12 and 13) directions respectively. Based on Figure 1 can be determined safely zone for evacuation and relocation, which is in from the North to the North East-East (zones 1 to 3 ).

\section{Radionuclide Dispersion Analysis}

\section{a. Dispersion Parameter $\mathrm{X} / \mathrm{Q}$}

Dispersion parameter $X / Q$ is influenced by radius distance and source term. Dispersion parameter $X / Q$ decreases with increasing source term and radius distance of release. To determine the influence of the radius distance and release time to the dispersion parameter of fission product in the Sebagin-West Bangka site are listed in Figure 2. 


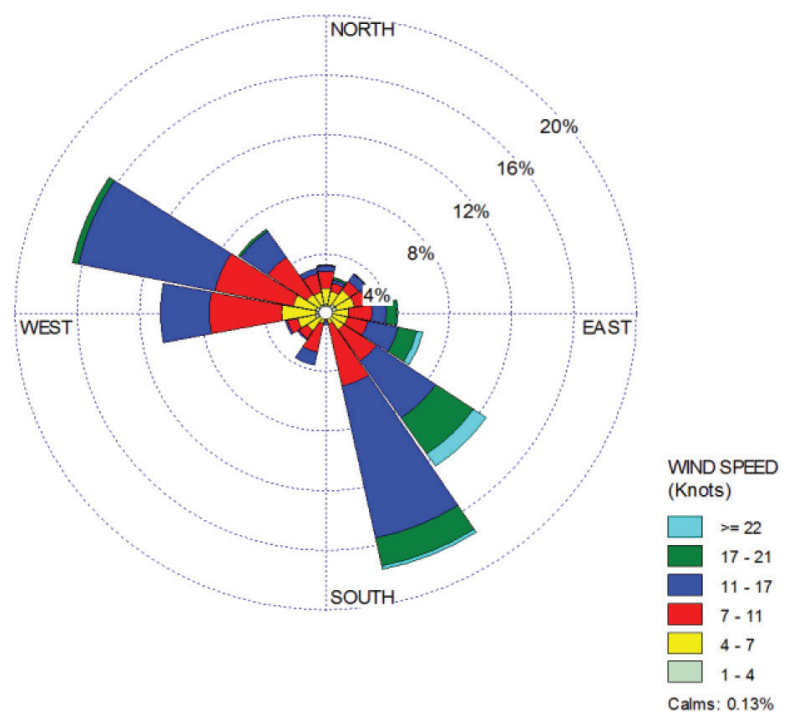

Figure 1: Anti wind rose (wind direction from NPP to Environment) of Sebagin Meteorology Station on West Bangka District.

Figure 2 shows that the dispersion parameter $(X / Q)$ decreases as a function of time. It is also seen that the dispersion parameter also decreases as a function of distance. The highest dispersion parameters shown in the exclusion area is within a radius of $800 \mathrm{~m}$ from the reactor site. While the influence of disperse time as it relates to sequences release, ie release sequences under 8 hours have dispersion parameter $(X / Q)$ is small, as it assumed that the source term still a small portion is released into the atmosphere. Figure 2 shows that the source term can be assumed to be whole releases to the atmosphere in the sequence of 24 - 96 hours.

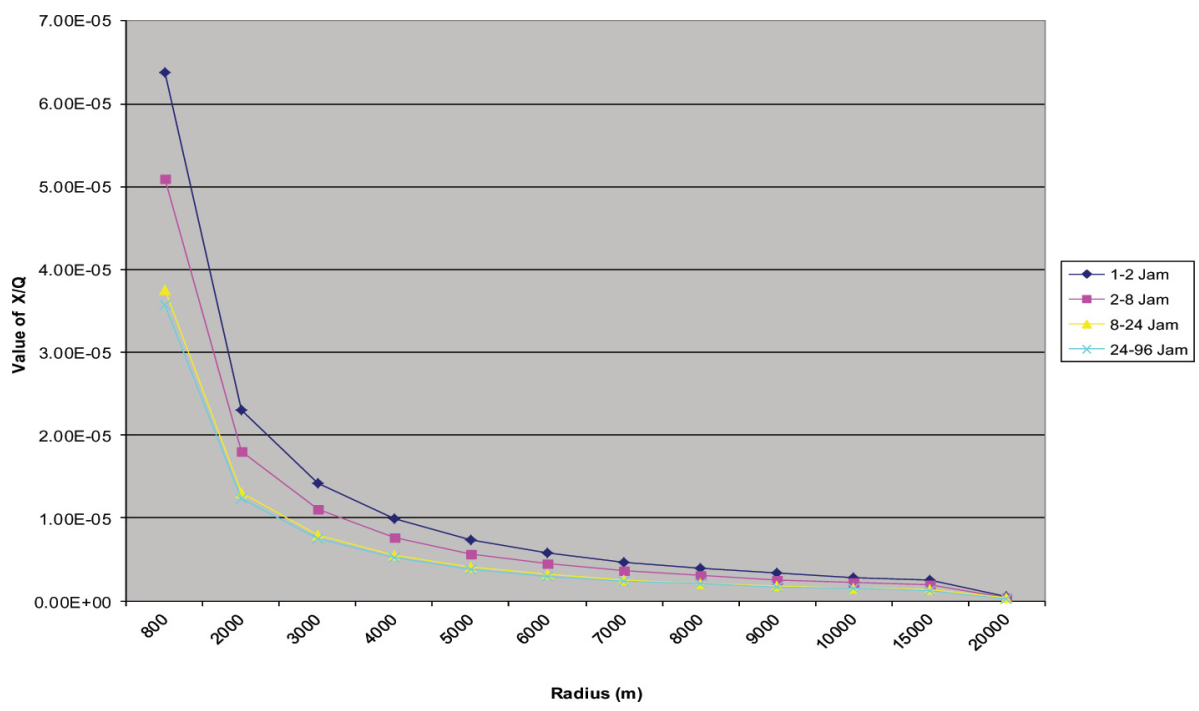

Figure 2: Dispersion Parameter ( $\mathrm{X} / \mathrm{Q})$ Fungsion of Time and Radius.

\section{b. Radionuclide Disperse Activity}

Activity of radionuclide radiation dispersed through the air pathway be affected by the value of the dispersion parameter $(X / Q)$, it mean that, by increasing the amount of activity it will increasing the dispersion parameter $(X / Q)$ value as well. The calculation results of radiation activities are shown in Figure 2 and Figure 3. 
Figure 3 shows the distribution of radionuclides through air pathway decreases as a function of distance and it is proportional to the decrease of dispersion parameter value ( $\mathrm{X} / \mathrm{Q})$ as shows in Figure 2. Figure 3 show that the greatest activity in a radius of $800 \mathrm{~m}$ in prospective nuclear power plant site which is an exclusion zone. Furthermore, from Figure 4 shows that the largest contributor of radionuclide exposure came from the I-131 at 52\%, followed by Xe-133 by $40 \%$, $\mathrm{Cr}-85 \mathrm{M}$ by $5 \%$ and $\mathrm{Te}-132$ by $3 \%$.

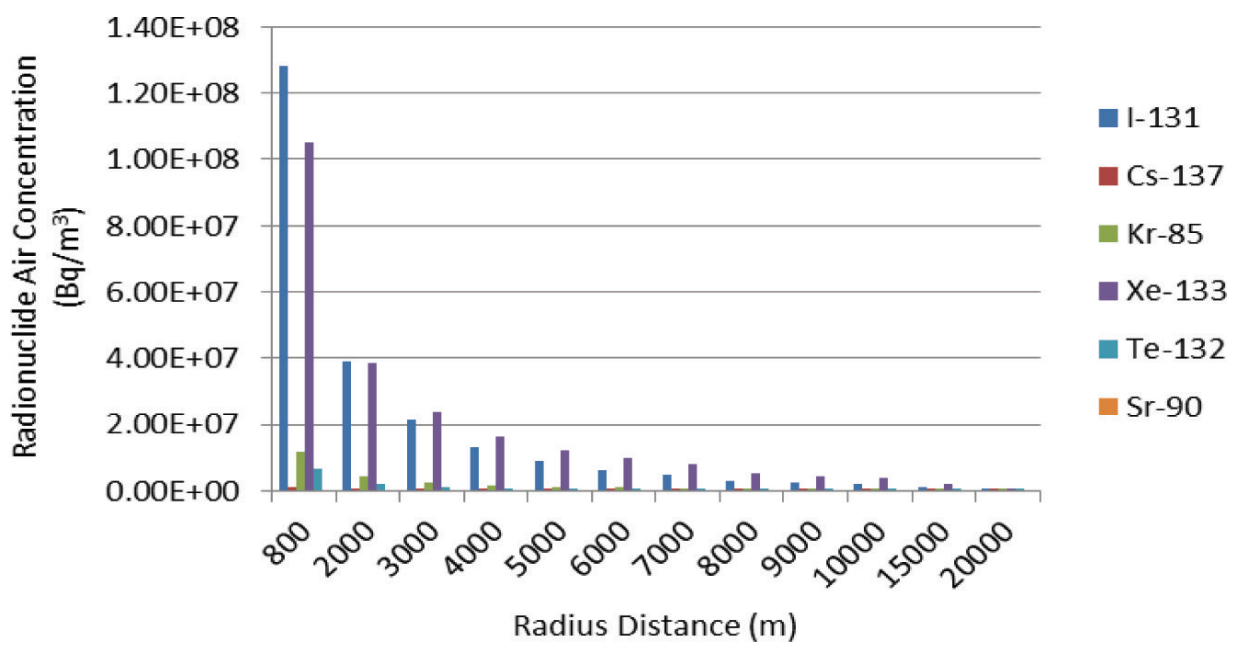

Figure 3: Radionuclide Air Concentration Function of Radius.

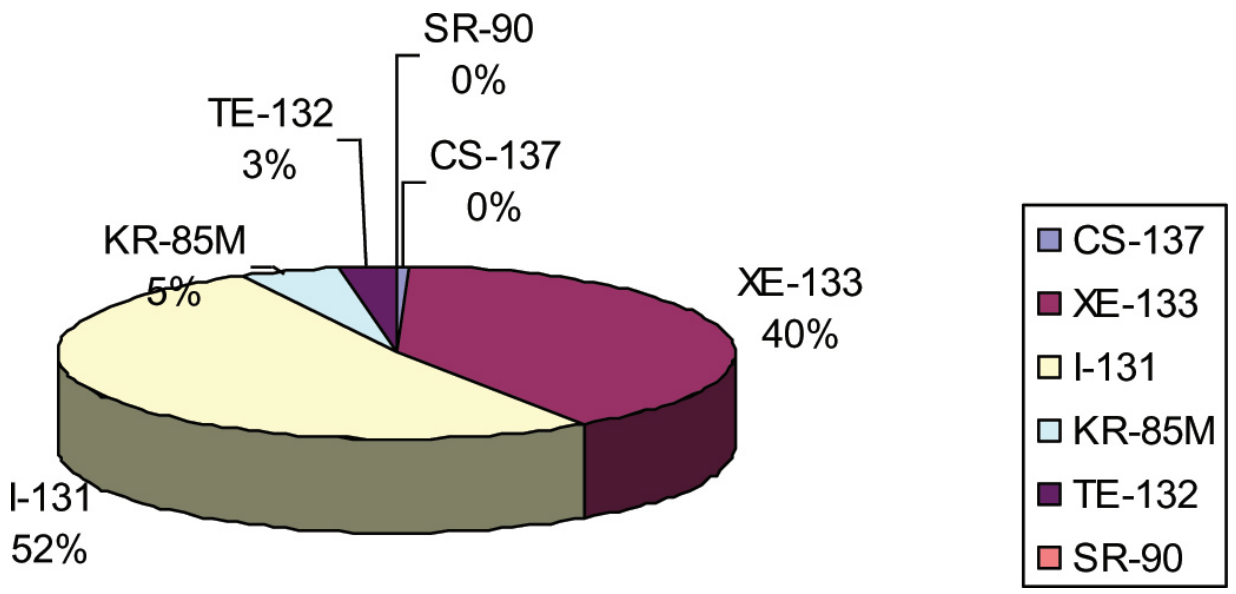

Figure 4: Percentage of Radionuclide Dispersion Release.

\section{Conclusion}

The dispersion analysis of the PWR to the environment on a severe accident condition using MACCS code has been done for in the Sebagin-West Bangka site. The analysis were carried out for 24 - 96 hours after the accident occur, where in that period the whole of radionuclides has been disperse from the reactor to the environment. Dispersion parameter decreases as a function of radius from the nuclear power plant site. The largest dispersion parameter is $6.30 \mathrm{E}-$ 05 in radius $800 \mathrm{~m}$ from reactor site. Also obtained radionuclide activity dispersed through the air to the environment and the percentage of this radionuclides respectively. The largest 
activity and percentage of radionuclide disperse to the air is come from I-131 radionuclide with value are of $1.24 \mathrm{E}+08 \mathrm{~Bq} / \mathrm{m}^{3}$ and $52 \%$ respectively. By obtaining dispersion factor and radionuclide activity dispersed through the air, then the purpose of this research have been achieved.

\section{References}

[1] Robert M, Csilla V, Istvan L, Simulation of Accidental Release Using a Coupled Transport (TREX) and Numerical Weather Prediction (ALADIN) Model, Quarterly Journal of the Hungarian Meteorological Service, Vol. 114, No. 1-2, January - June 2010, pp. 101-120

[2] Moosung J, Seok W.H, A Study on Risk Assessments Using the MACCS Code for a Nuclear Power Plant, Journal of Nuclear Science and Technology, Supplement 4, P 418-422, March 2004

[3] Chanin D.I, Sprung J.I and colleagues MELCOR Accident Consequence Code System (MACCS) User Guides, U.S Nuclear Regulatory Commission, Washington, DC 20555, 2010

[4] Juliana P.D, Paulo F. F, and colleagues, Atmospheric Dispersion and Dose Evaluation Due to the Fall of a Radioactive Package at a LILW Facility, International Journal of Energy Engineering, Vol 3, p 119-126, 2013

[5] G.D. Rolpha, F. Ngana, R.R. Draxler, Modeling The Fallout from Stabilized Nuclear Clouds Using The HYSPLIT Atmospheric Dispersion Model, Journal of Environmental Radioactivity, Volume 136, Pages 41-55, October 2014

[6] Till J. E, Rood A.S, and colleagues, Comparison of the MACCS2 Atmospheric Transport Model with Lagrangian Puff Models as Applied to Deterministic and Probabilistic Safety Analysis, Journal of Health Physics, Volume 107 - Issue 3 - p 213-230, September 2014

[7] François V. D, Bertrand L,Vladimir S, and colleagues, Atmospheric Transport Modeling with 3D Lagrangian Dispersion Codes Compared with SF6 Tracer Experiments at Regional Scale, Science and Technology of Nuclear Installations, Volume 2007 (2007), Article ID 30863, 13 pages

[8] Pande. M.U, dan Widodo, S. Penentuan Koefisien Dispersi Atmosferik untuk Analisis Kecelakaan Reaktor PWR di Indonesia, Jurnal Teknologi Reaktor Nuklir Vol. 14 No.2 Juni 2012, Hal. 121-132

[9] Pande M. U, Sri K, Pane J.S., Analisis Kecelakaan Parah pada Pressurized Water Reaktor dengan Backwards Method, Jurnal Teknologi Reaktor. Nuklir Vol. 15 No.1 Februari 2013, Hal.12-26

[10] Scott G.A, Kenneth C.W, and colleagues, Assessment of Severe Accident Sourceterms in Pressurized-Water Reactors with a 40\% Mixed-Oxide and 60\% Low- Enriched Uranium Core Using MELCOR 1.8.5, SANDIA National Laboratories, Printed April 2010.

[11] X. Davoine and M. Bocquet, Inverse modeling-based reconstruction of the Chernobyl source term available for long-range transport, Atmos. Chem. Phys., 7, 1549-1564, 2007, P 1550-1558

[12] Joong M.Y, Glaser R. Atmospheric Dispersion Analysis Using MACCS2, International Congress on Advances in Nuclear Power Plants, (ICAPP '04). Pittsburgh. PA; 2004; June 13-17, United States; 2004. 